\title{
AIR TRANSPORT SECURITY: THE ROLE OF THE CAI - CAPC - RENEGADE CONCEPT
}

\author{
BOHDAN PASZUKOW \\ Securitas Transport Aviation Services
}

RYSZARD PIWOWARCZYK

Wojskowa Akademia Techniczna

\begin{abstract}
In this short article the authors describe the main components of the basic cooperation on the "CAI - CAPC - RENEGADE" concept and its significance for the common air traffic monitoring and control system. Such system involves among the others countering the possible airborn terrorist threats. Cooperation between the NATO countries and Russia has been noticed in the article, as well as its importance for the unified protection countries against the airborn activities and its military significance.
\end{abstract}

Keywords. CAI-CAPC-RENEGADE, air traffic monitoring, terrorist threats

The October 2005 statement of Russia's Ministry of Foreign Affairs called for special trust and cooperation building measures on the borders along the Baltic coast, the development of which the Russian side had repeatedly suggested. A special significance of this issue would be an increase in the pace of implementation of the NATO-Russia Council [NRC] project on a common air traffic monitoring and control system, which could also be a means to counter potential airborne terrorist threats, the statement noted.

Six years later, NATO and Russia are getting ready to operationalize this special joint air traffic monitoring and control system. This project, with potential to assure both Central and Easter European (CEE) states and Russia, is the NRC Cooperative Airspace Initiative (CAI). The NRC working group developed an operational concept for a Cooperative Airspace Initiative (CAI) an effort to implement a joint NATO-Russia capability for air traffic management interoperability to enable the reciprocal exchange of air traffic data.

By the summer of 2003, the NRC had allocated funding for a CAI feasibility study. In the meantime, the project's political importance was reiterated in the 2004 NATORussia Action Plan on Terrorism. CAI's importance as a tool for promoting regional security was reaffirmed after the crash of the Russian Su-27 in Lithuania in 2005. A press release issued by the Russian mission to NATO focused on the importance of the underlying goals of the Initiative enhancing transparency and predictability of the regional airspace. The project even endured the chill in NATO-Russian relations 
following the 2008 Caucasus conflict. Now the CAI is a crisis management arrangement that seeks to facilitate a continuous exchange of ground sensor data tracked 150 kilometers along each side of the border in three pairs of FIRs between Russia and NATO.

The initiative's objectives include the detection of and notification about a potential renegade and the continuity of real-time air track information for the purpose of coordination of action between CAI participants and obtaining alerting notification on aircraft outside the national airspace limits. At present, the transmission of sensor data is filtered and restricted to the tracking of civil aviation. However, from its inception, CAI was intended for the exchange of data on both civil and military air traffic.

In practical terms, the project has involved the creation of a total of eight communication nodes (four in Russia, two in Poland, and one in Norway and Turkey, respectively) with several computer terminals each. Out of these nodes, six local communication units (LCU) facilitate the exchange of data from national ATC centers to one NATO coordination center (CC) and one Russian CC. Upon the detection of a potential "renegade", a national ATC center informs its LCU which, in turn, informs the respective CC. The CC, in turn, informs its counterpart CCs.

These nodes are connected through digital data links and voice coordination circuits. The three Russian LCU, are connected to one another through digital data links and the same goes for the three NATO LCUs. However, a NATO LCU is not set up to receive digital data from its Russian FIR counterpart, and vice versa. Instead, the digital data (and voice) exchange occurs only through the two CC set up in Warsaw and Moscow, respectively.

As of April 2010, approximately 10 million Euros total had been invested into the CAI by Russia and eleven NATO states. These NATO states included Canada, France, Greece, Hungary, Italy, Luxembourg, Norway, Poland, Turkey, UK, and the U.S. An expansion of the NRC CAI to additional states through CIMACT would be both technically feasible and cost effective today.

At the Prague Summit, the Alliance agreed to establish a Military Concept encompassing the organisation's principles of intervention in regard to international terrorism and the various actions envisaged. This directive, known as MC-472, was approved in December 2002 and outlines the different roles which NATO may play, which are basically two: to lead an operation or to support a nation or coalition of nations in the fight against international terror.

The Military Concept for the fight against terror, approved unanimously, sets forth certain political criteria: the Alliance's actions in the fight against terrorism must be in line with international law, must be approved by the UN and must uphold Human Rights. They will be aimed at helping to dissuade and prevent any terrorist attack against populations, territory, infrastructure or forces pertaining to NATO countries. Support operations to third parties will be studied and approved on a case-by-case basis, at the request of the said third parties. 
The Military Concept envisages four types of action by NATO:

(1) antiterrorism actions (AT);

(2) counter-terrorism actions (CT);

(3) consequence management (CM); and

(4) military cooperation (MC).

There follows a brief overview of each:

Antiterrorist actions are mainly defensive and aimed at lowering the degree of vulnerability and, if possible, thwarting any terrorist attack. These actions include those aimed at creating an intelligence community that shares information, using early warning systems to prevent attacks, deploying naval defence systems and the NATO Integrated Air Defence System (NATINADS), which even envisages the possibility of shooting down passenger aircraft in the event of being certain that it has been hijacked and will be used as an aircraft-missile, as on 9/11. These are known as renegade aircraft.

Furthermore, NATO proposes to establish standard requirements in regard to protection of its forces acting outside NATO territory, including rapid response capabilities. Other antiterrorist operations include non-combatant evacuation operations (NEO) in third-party countries.

The possibility that terrorist organisations might acquire long-range missiles in the illegal weapons market and even that they might be loaded with WMD, has led the Alliance to consider the provision of anti-missile defence systems. It is worth recalling that the responsibility for the protection of countries' infrastructures and population is first and foremost for the national governments and that what NATO does is support these governments when asked to.

With Consequence Management, NATO tries to apply measures to mitigate the destructive effects of terrorist attacks. Basically, the idea is to support the civil authorities, for which purpose the armed forces must have the necessary capabilities. This is especially important in the event of a terrorist attack with weapons of mass destruction, considering that the Alliance forces have units of WMD protection and decontamination. Considering that consequence management in any attack is the responsibility of the country's authorities, NATO will offer its help and support to cooperate with said authorities, but will never act as leader in this kind of operations.

Finally, military operations seek to coordinate efforts in the fight against terrorism between countries via international organisations such as the UN, the OSCE, the EU, etc., generating public confidence via good relations with influential civil bodies. In this regard, NATO has vast experience via its cooperation programs, most notably: Partnership for Peace (PfP) with Russia’s former Warsaw Pact partners, associations with Russia and the Ukraine (NATO/Russia Founding Act and NATO/ Ukraine Commission) and the Mediterranean Dialogue. Considering the origin of Islamic terrorism, the latter is especially significant, as was highlighted at the Istanbul Summit in June 2004. 
The air space protection principles during peace for supporting the integrity of European air space of NATO, for protecting NATO countries and their forces from air attacks are based on set rules and standards of NATO. The International Military Staff(IMS) prepares a document to elaborate the issue of NATINADS more in detail. The mentioned document defines the term RENEGADE, defines the competences, responsibilities and methods of command and control for individual command levels of NATO and for military as well as civil organs of control of air traffic when preparing measures, coordination and intervention against objects such as RENEGADE If this is the case, the state in line with the international law must avoid the decision to use weapons against a civil aircraft and it must accept all necessary measures to secure and lead the civil aircraft in accordance with the competent rules, standards and recommended methods included in the Chicago Convention and its amendments. The state must not be passive if it faces a RENEGADE object threat.

Obviously, according to international law principles, no sovereign state has limits that could prevent it from reacting in case of violation of its territorial integrity or political independence, or if its principles related to the state's responsibilities are violated in some ways. Sovereign states face the threat of using force against their territorial integrity or political independence by launching corresponding activities, which will secure their preparation for averting the threat by activating the elements of air space defence.

Any state is responsible for protecting its territorial integrity and political independence, which also includes protection of its national interests and people within its territory. Under certain circumstances the activity against RENEGADE object can be justified by the protection of these legitimate interests. If it is necessary the state is authorized to use force to protect itself from activities which would violate its independence. In this case we must consider activities against the object that violates the state sovereignty and independence as well as security of the citizens who are entitled to protection and freedom, too. It is not important if the intruder uses civil or military approaches. It is the intention that is important.

In case of RENEGADE object, the goals and intentions of the intruder might be achieved by direct action, which can then cause corresponding reactions of the competent state. When mentioning about the CAI and RENEGADE procedure it is always worth to clarify the role and meaning of CAPC. CAPC plans for the provision of air transport of persons and goods in crisis or war CAPC planning takes account of the world-wide inter-relation of all aviation activities and seeks access to air assets, equipment and facilities to meet the Alliance needs. In particular, the current responsibilities of CAPC are:

1. Plan to make civil aviation capability available to meet alliance requirements in crisis and war through appropriate civil aviation crisis management arrangements. 
2. Plan for the availability of war risk insurance for commercial aircraft supporting the Alliance.

3. Pursue joint planning with the NATO Military Authorities; and

4. Assess the legislative or other powers that nations can call upon in a crisis short of war in order to provide civil aviation support to the Alliance.

\section{Conclusion}

NATO has demonstrated its firm decision to contribute to the fight against global terrorism and it is the most deeply involved of all international organisations in terms of troop numbers. The Alliance has been unwavering in undertaking the most sweeping reform in its history in order to face the new threats. Terrorist activities of individuals or organized groups and international networks are extremely dangerous for international security. Thus, the armed forces must be ready to support the organs of state power or even assume full responsibility for fighting terrorism.

The protection of air space of SR within NATINADS should be viewed from two main perspectives: (1) activities against military and unidentified air objects under the command of Combined Air Operations Centre (CAOC), (2) activities against any civilian air object used as a terrorist weapon, the co-called RENEGADE, which are exclusively in the competences of NGA - National Governmental Authority, which has right to use national forces selected for NATINADS.

After the 9/11 all countries over the world faced a completely new form of terrorism - air terrorism threat using civilian aircrafts as weapons. The term RENEGADE is used to define civilian aircrafts that are suspected of being used as weapons to perform terrorist attacks. Dealing with the concept of RENEGADE is connected with the problem of protecting air space. We can simply say that the activities against an air target such as RENEGADE are a specific part of protection of air space.

\section{BEZPIECZEŃSTWO TRANSPORTU LOTNICZEGO: ROLA KONCEPCJI „CAI - CAPC - RENEGADE”}

Streszczenie: W tym zwięzłym artykule autorzy opisują najważniejsze elementy systemu kooperacji bezpieczeństwa lotniczego, znanego z angielskiej nazwy "CAI - CAPC - RENEGADE". Jego konceptualizacja oraz znaczenie dla monitorowania przelotów statków powietrznych i systemu kontroli ma duże znaczenie dla bezpieczeństwa niejednego kraju. System ten ma możliwości przeciwdziałania lotniczym atakom terrorystycznym. Jego znaczenie jest rozpoznane w ramach współpracy między NATO i Rosją. Ten zunifikowany system bezpieczeństwa lotniczego ma oczywiście również zastosowanie militarne. Keywords: CAI - CAPC - RENEGADE, kontrola ruchu powietrznego, zagrożenia terrorystyczne 